\title{
The effect of weed frequency in the overall alfalfa (Medicago sativa L.) productivity, case study from Kosovo
}

\author{
Enver SHERIFI $^{1}$, Naim BERISHA ${ }^{1 *}$
}

Received January 04, 2018; accepted January 25, 2019.

Delo je prispelo 04. januarja 2018, sprejeto 25. januarja 2019.

\begin{abstract}
Alfalfa (Medicago sativa L.) represents an important leguminous forage crop in farming as well as in systems of animal husbandry. It is known for its wide usage for grazing, hay, silage as well as in the form of green manure and cover crop. Our study aims to assess the influence of weeds on quality and quantity of three different aged alfalfa plots. A list of registered weed plant species divided by harvesting periods on each of the surveyed plots is offered. The biomass productivity and its correlation to the effects of artificial fertilizers, alfalfa age and the frequency of weeds are provided. We concluded that using mineral fertilizers in a controlled manner will help to reduce considerably the amount of weeds and also that alfalfa crops will be best to be replaced after four years as its productivity will start afterwards to drop sharply, whereas the number and frequency of weeds will increase conversely.
\end{abstract}

Key words: alfalfa; weed management; forage crops

\section{IZVLEČEK}

\section{UČINEK PLEVELOV NA PRIDELEK LUCERNE (Medicago sativa L.), VZORČNA ŠTUDIJA S KOSOVA}

Lucerna (Medicago sativa L.) predstavlja $\mathrm{v}$ kmetijstvu pomembno krmno metuljnico kot integralni del živinorejskih sistemov. Njena uporabnost je zelo široka, od paše, priprave sušene krme, silaže, kot zeleno gnojilo in pokrovna rastlina. Namen te raziskave je oceniti vpliv plevelov na količino in kakovost pridelka lucerne na treh različno starih posevkih. Vključena je lista plevelov, ki so se pojavljali na teh ploskvah v odvisnosti od časa košnje. Produkcija biomase je prikazana $\mathrm{v}$ odvisnosti od učinkov gnojenja $\mathrm{z}$ mineralimi gnojili, starosti posevka in pogostosti plevelov. Na osnovi rezultatov lahko zaključimo, da lahko uporaba mineralnih gnojil na primeren način znatno zmanjša količino plevelov in, da je potrebno posevek lucerne zamenjati po štirih letih, ker njegova donosnost potem obdobju znatno upade, poveča pa se zapleveljenost.

Ključne besede: lucerna; upravljanje plevelov; krmne rastline

\section{INTRODUCTION}

Among all of the forage crops, alfalfa is considered to be one of the most important one due to being source of proteins, minerals, particularly vitamin A (Raoofi et al., 2014; Karimi, 2007) and also due to its verified role in improving soil structure as well as multiplier of other ecological functions and its unique ability to grow in semiarid areas ( $\mathrm{Gu}$ et al., 2018; Zhao et al., 2004; Jefferson \& Cutforth, 1997). Alfalfa's forage yield is entirely dependent on a variety of factors, like soil conditions, rainfall availability and soil moisture (Fan et al., 2016). This indicates its high water demand and also reflects its biological ability of nitrogen fixation (Shabani et al., 2017; Wang et al., 2018). Anyhow, one of the biggest challenges in alfalfa's yield productivity still remains the presence of weeds, which harshly compete with the main plant for sources of light, moisture and nutrients (Wilson, 1997). Besides of suppressing the overall alfalfa yield, weeds can also impact the densities of alfalfa stands (Becker et al., 1998). In many studies it has been proven that weed interference with alfalfa also causes reduction in quality as well as yield quantity, decreasing its trade price for about $46 \%$ (Boschetti et al., 1998; Wilson \& Burgener, 2009; Riley \& Bradley, 2014) and its overall density by 20-30\% (Temme et al., 1979), all this being followed by drastic reduction of alfalfa nutritional values (Doll,

1 Faculty of Mathematics and Natural Sciences, University of Prishtina "Hasan Prishtina", Prishtina, Kosovo; *corresponding author: naim.berisha@uni-pr.edu 
1986). Weeds also do interfere with alfalfa in other aspects, like reducing alfalfas' edibility (Marten et al., 1987), seedling efficiency (Fischer et al., 1988) and also altering the forage normal composition, increasing as a result the drying time (Doll, 1986).

It has been noted that in particular, alfalfa seedlings are vulnerable to weed competition, as they are not impetuous enough to compete with weeds, and this, as with many other crops, results in reduced yields (Zimdahl, 2004; Wilson, 1981).

Knowing all this, regrettably, weeds in forage crops have not had sufficient attention and this will surely lead to serious quality and quantity damages of alfalfa crop. Additionally, crop nutritional values for livestock feeding will also decrease, an issue that particularly in Kosovo has never been a subject of attention.

This study brings an insight of the weed effect and interference with alfalfa, identification of weed species and their distributional frequency before first, second and third harvest accordingly. Weeds direct affect alfalfa productivity, biomass levels and correlation of these values with alfalfa age, soil and ecological conditions of the given studied site.

\section{MATERIAL AND METHODS}

Weed survey on alfalfa land parcels was conducted during 2016, starting from April until the end of September. All of the recorded plant species (Annex 1) were identified based on Flora Europaea (Tutin et al., 1964 - 1980) and species naming has followed the Euro Med Checklist (Euro+Med, 2006) nomenclature. We have choosen three alfalfa plots (Medicago sativa L. em Vass. - K-22 'Kruševaćka' commercial cultivar) in the village of Zotaj $\left(42^{\circ} 27.051 \mathrm{~N}, 021^{\circ} 06.854 \mathrm{E}\right)-20 \mathrm{~km}$ south from capital Prishtina. The site is characterized with continental climate, with a mean annual temperature of $10.5^{\circ} \mathrm{C}$ and mean monthly temperatures of $20.6{ }^{\circ} \mathrm{C}$ (July) and $-1.4{ }^{\circ} \mathrm{C}$ (January). The mean annual precipitation from 1999 to 2016 was $590 \mathrm{~mm}$, of which months with the highest amount of rainfall are May, October and November. We have analyzed in particular: weed species present, biomass at $1 \mathrm{~m}^{2}$, alfalfa mass at $1 \mathrm{~m}^{2}$, weed mass at $1 \mathrm{~m}^{2}$, overall yield per land parcel as well as weed species composition in floristic terms. Plant material has been surveyd and collected in three different time perioids (first - April/May; second June/July; third - August/September) - always just before the harvest.

\section{7 year / average monthly precipitation}

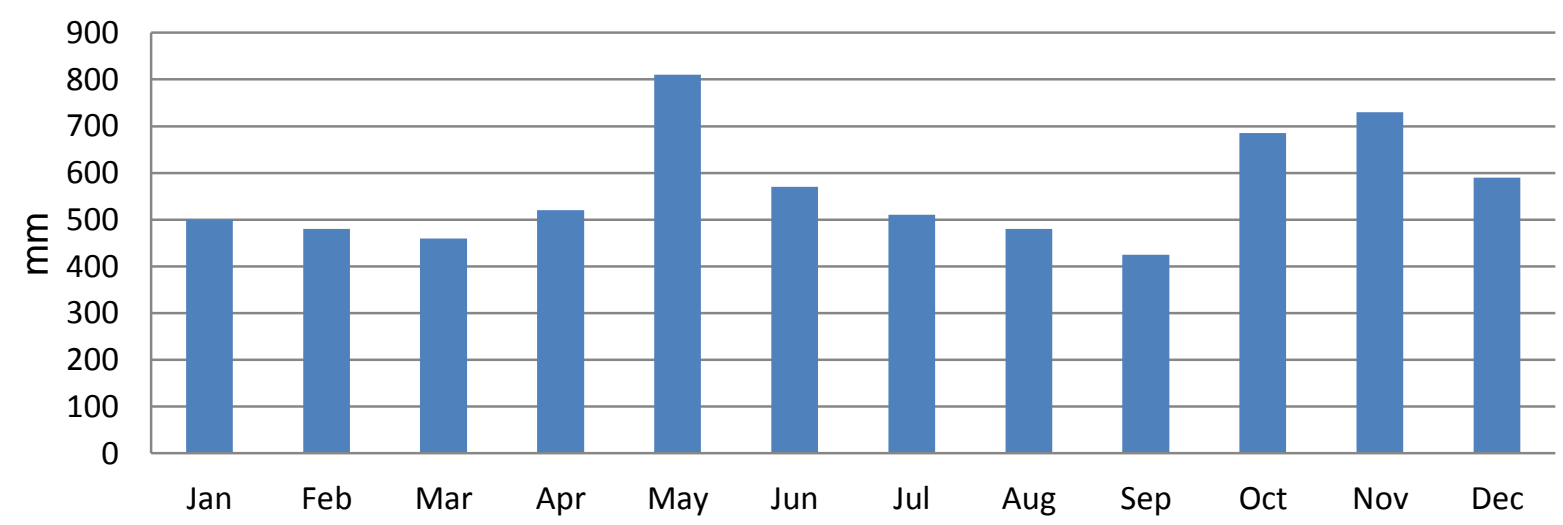

Figure 1: Rainfall data overview for a period of 17 years in Zotaj.

We have selected three alfalfa land parcels and on each of them we have made a total of ten measurements at $1 \mathrm{~m}^{2}-$ repeatedly before first, second and third harvest. Parcel details are as following: Parcel 1 - sown with alfalfa 6 years ago, has not been treated with mineral fertilizers, previous agricultural crop was wheat, $240 \mathrm{~m}$ above sea level (a.s.l). Parcel 2 - sown with alfalfa 4 years ago, treated with mineral fertilizers, previously was ploughed land, $220 \mathrm{~m}$ a.s.l. Parcel 3 - sown with alfalfa 2 years ago, treated with mineral fertilizers, previously was ploughed land, $222 \mathrm{~m}$ a.s.l. All three parcels were really flat, so we could not indicate their exposition. 


\section{RESULTS AND DISCUSSION}

Knowledge on abundance and distribution of weed species within a given landscape of an agroecosystem is a valuable goal for weed science. Abundance and distribution as measures of the number of individuals in an area and a measure of the geographical range of a weed species accordingly are essential units in this context. The study of weed population's abundance and distribution is helpful in determining how a population changes over time in response to discerning pressures applied by agronomic practices.

During our survey we continuously measured biomass level, alfalfa mass and weed mass at three selected plots of alfalfa and the obtained results are presented in three parts, according to the harvest. We have continually made ten relèves of $1 \mathrm{~m}^{2}$ on each of the three parcels, at three different pre-harvest periods.

\subsection{First preharvest}

During the first preharvest period, we made our survey from $27^{\text {th }}$ until the $29^{\text {th }}$ of May 2016. Parcel one (alfalfa 6 years old), after ten relèves had on average $22.5 \%$ weeds and $77.5 \%$ alfalfa. Parcel two (alfalfa 4 years old), after ten relèves had on average $13.8 \%$ weeds and $86.2 \%$ alfalfa. Parcel three (alfalfa 2 years old), after ten relèves had on average $8.2 \%$ weeds and $91.8 \%$ alfalfa. Biomass production at the pre-first harvest period was as following: $1^{\text {st }}$ parcel: $8.2 \mathrm{~kg} \mathrm{~m}^{-2}, 2^{\text {nd }}$ parcel: $9.1 \mathrm{~kg} \mathrm{~m}^{-2}, 3^{\text {rd }}$ parcel: $11.07 \mathrm{~kg} \mathrm{~m}^{-2}$ (Figure 2).

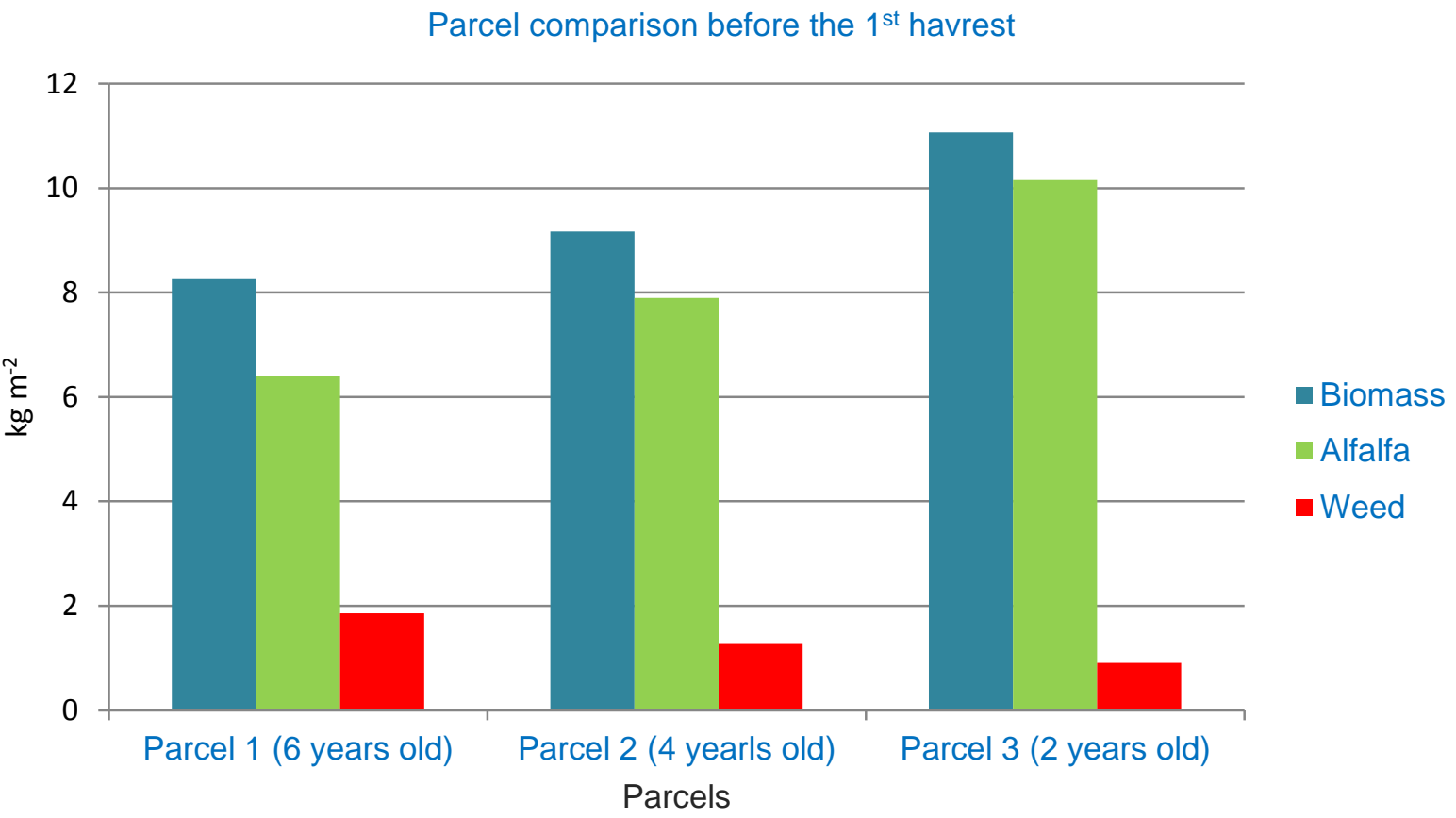

Figure 2: Parcel productivity comparison before the first harvest $\left(\mathrm{kg} \mathrm{m}^{-2}\right)$.

\subsection{Second preharvest}

During the second preharvest period, we made our survey from $10^{\text {th }}$ until the $12^{\text {th }}$ of July 2016. Parcel one (alfalfa 6 years old) after ten relèves had on average $21.5 \%$ weeds and $78.5 \%$ alfalfa. Parcel two (alfalfa 4 years old), after ten relèves had on average $12.1 \%$ weeds and $87.9 \%$ alfalfa. Parcel three (alfalfa 2 years old), after ten relèves had on average $7.5 \%$ weeds and $92.5 \%$ alfalfa. Biomass production at the second preharvest period was as following: $1^{\text {st }}$ parcel: $7.6 \mathrm{~kg} \mathrm{~m}^{-2}, 2^{\text {nd }}$ parcel: $8.2 \mathrm{~kg} \mathrm{~m}^{-2}, 3^{\text {rd }}$ parcel: $10.2 \mathrm{~kg} \mathrm{~m}^{-2}$ (Figure 3). 
Parcel comparisoon - $2^{\text {nd }}$ harvest

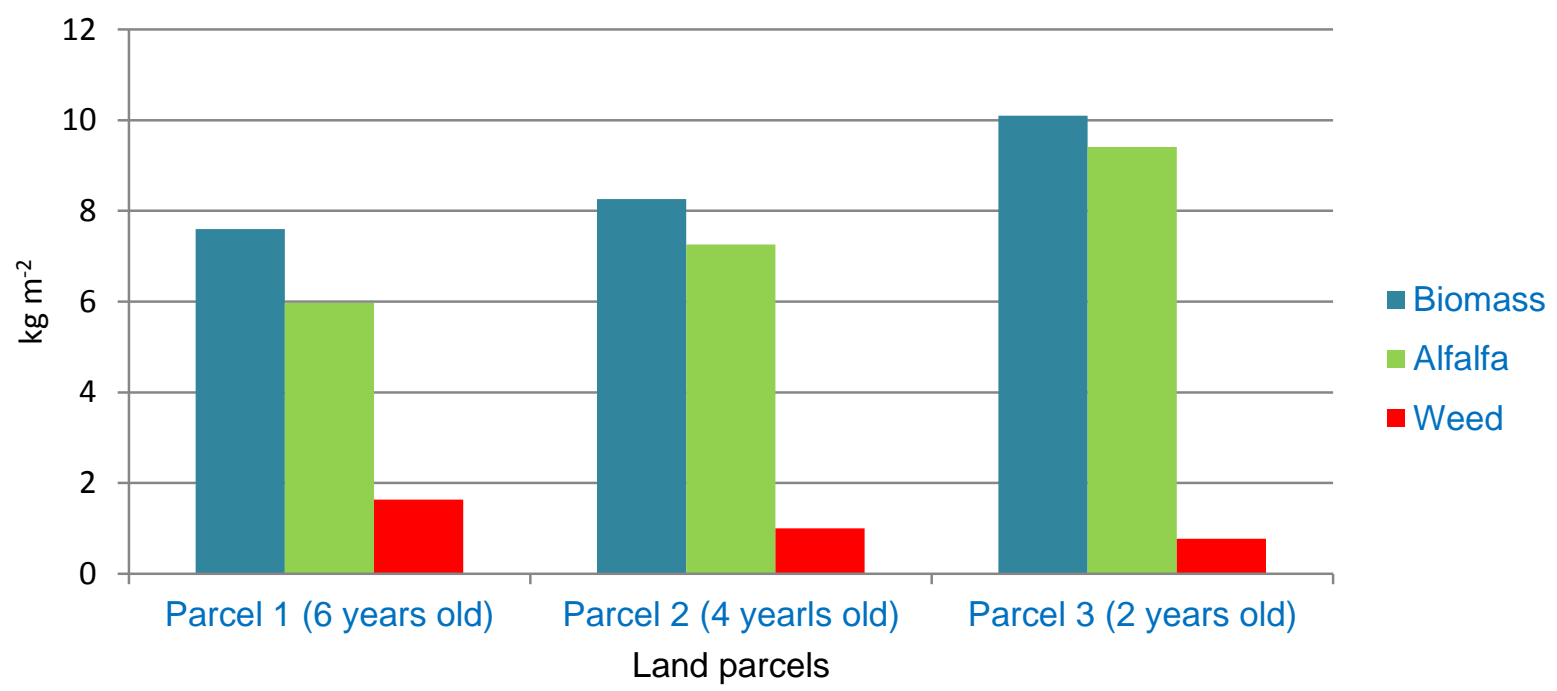

Figure 3: Parcel productivity comparison before the second harvest $\left(\mathrm{kg} \mathrm{m}^{-2}\right)$.

\subsection{Third preharvest}

During the third preharvest period, we made our survey from $13^{\text {th }}$ until the $15^{\text {th }}$ of September 2016. Parcel one (alfalfa 6 years old), after ten relèves had on average $17 \%$ weeds and $83 \%$ alfalfa. Parcel two (alfalfa 4 years old), after ten relèves had on average $9.8 \%$ weeds and $90.2 \%$ alfalfa. Parcel three (alfalfa 2 years old), after ten relèves had on average $6.05 \%$ weeds and $93.9 \%$ alfalfa. Biomass production at the prethird harvest period was: $1^{\text {st }}$ parcel: $5.8 \mathrm{~kg} \mathrm{~m}^{-2}, 2^{\text {nd }}$ parcel: $6.4 \mathrm{~kg} \mathrm{~m}^{-2}$, $3^{\text {rd }}$ parcel: $8.7 \mathrm{~kg} \mathrm{~m}^{-2}$ (Figure 4 ).
Significant differences between parcels and preharvest times have been observed (Table 1) regarding the weed species composition, their distribution frequency and the distribution patterns as well as overall yield of alfalfa. Regarding the weed species present, significant differences have been observed between parcel one and parcel three, the same applies to their distribution frequency - and their frequency and presence was higher in the first preharvest time, compared to the third preharvest time..

Table 1: ANOVA statistical table

\begin{tabular}{|c|c|c|c|c|c|c|}
\hline Source of Variation & $S S$ & $d f$ & $M S$ & $F$ & $P$-value & $F$ crit \\
\hline Between Groups & 12.6 & 2 & 6.3 & 0.50 & 0.03 & 2.2 \\
\hline Within Groups & 261.6 & 21 & 12.4 & & & \\
\hline Total & 274.3 & 23 & & & & \\
\hline
\end{tabular}

Differences were also observed in the following aspects: there was much higher productivity of alfalfa in the first preharvest and a drastic reduction in the third preharvest. We have also noticed that the amount and frequency of weeds directly affects the reduction of alfalfa yield. 


\section{Parcel comparison before the $3^{\text {rd }}$ harvest}

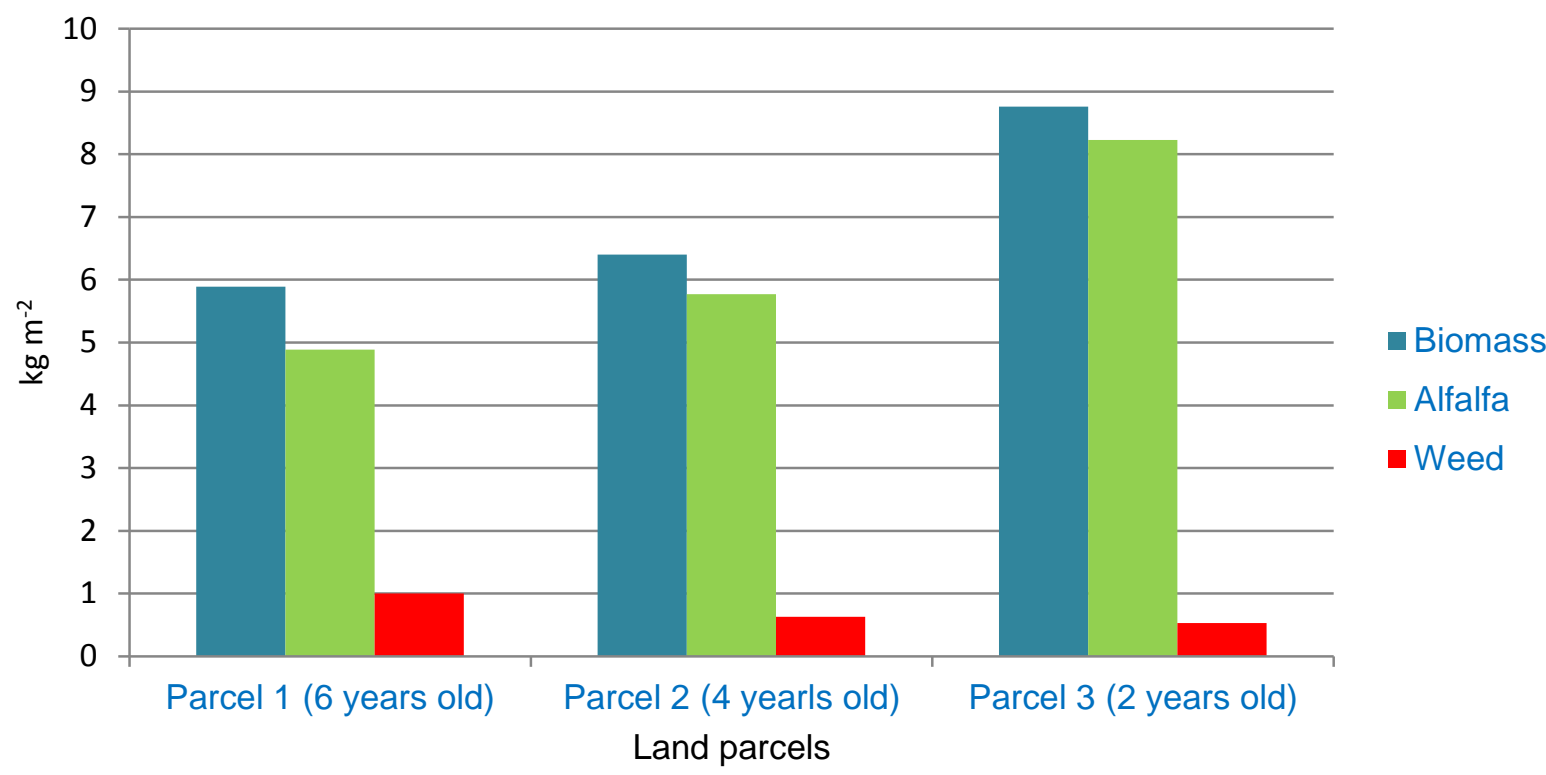

Figure 4: Parcel productivity comparison before the third harvest $\left(\mathrm{kg} \mathrm{m}^{-2}\right)$

It was observed that the number and frequency of weed distribution is directly related to the age of alfalfa stands. As older the alfalfa stand is, the greater will be the number of weeds on that given parcel. The role of mineral fertilizers is also important to be noted here, as it has been observed that alfalfa parcels that were not treated with fertilizers, the frequency of weeds vas much higher.

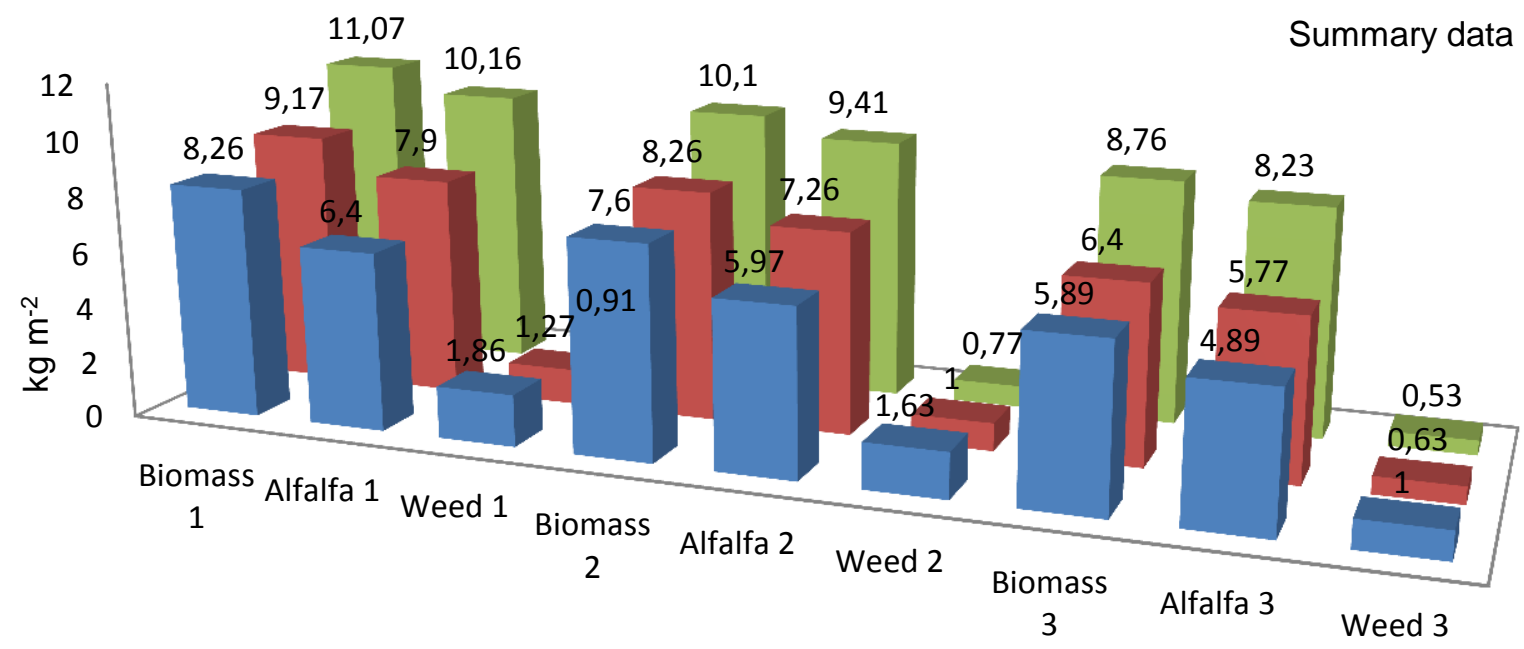

Parcel 1 Parcel $2 \square$ Parcel 3

Figure 5: Summary chart of biomass, alfalfa and weed data for all three parcels during three $(1,2,3)$ preharvesting periods 


\section{CONCLUSIONS}

Weed frequency is higher during the spring months due to the favorable ecological conditions such as sufficient humidity, solar radiation and biology of weed species. Higher alfalfa yield is expected during the four years from sowingand afterwards a yearly based decrease on yield will be noticed. During the all three pre-harvest periods, the number and frequency of weeds was always higher at the parcel one (alfalfa 6 years old), compared to parcels two and three. Alfalfa productivity was higher at parcel three (alfalfa 2 years old) compared to parcels two and especially parcel one. Predominant weed plant families were: Poaceae $\left(1^{\text {st }}\right.$ pre-harvest $)$, Fabaceae $\left(2^{\text {nd }}\right.$ pre-harvest) and Asteraceae ( $3^{\text {rd }}$ pre-harvest) while less represented families were Caryophyllaceae $(2 \%)$ and Violaceae $(1 \%)$ - Figure 5 . In total 71 plant species of weeds were recorded (Annex 1) in the surveyed plots. A correlation (Figure 5 \& Figure 6) between the increased presence of weeds and the lack of mineral fertilizers has been noted. Biomass productivity was for $29.9 \%$ higher at parcel three, compared to parcel one - which indicated that younger alfalfa is far more productive. As a general conclusion of this work we can state that based on the obtained results in our selected parcels, alfalfa is recommended to be cultivated for up to four years but no longer due to the optimal productivity rates.

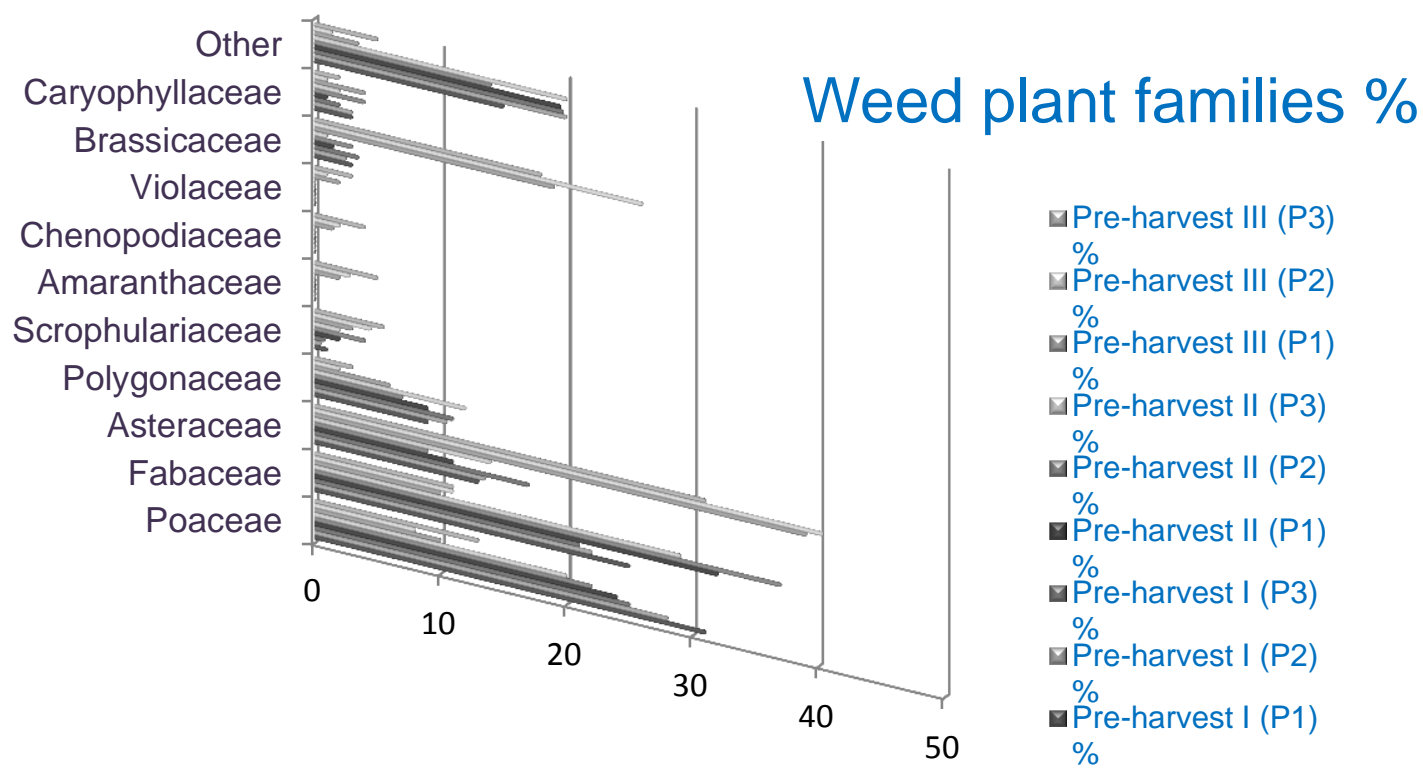

Figure 6: Plant families of weed species according to their pre-harvest time 
The effect of weed frequency in the overall alfalfa (Medicago sativa L.) productivity, case study from Kosovo

Annex 1. List of registered weed plant species in three studied alfalfa parcels

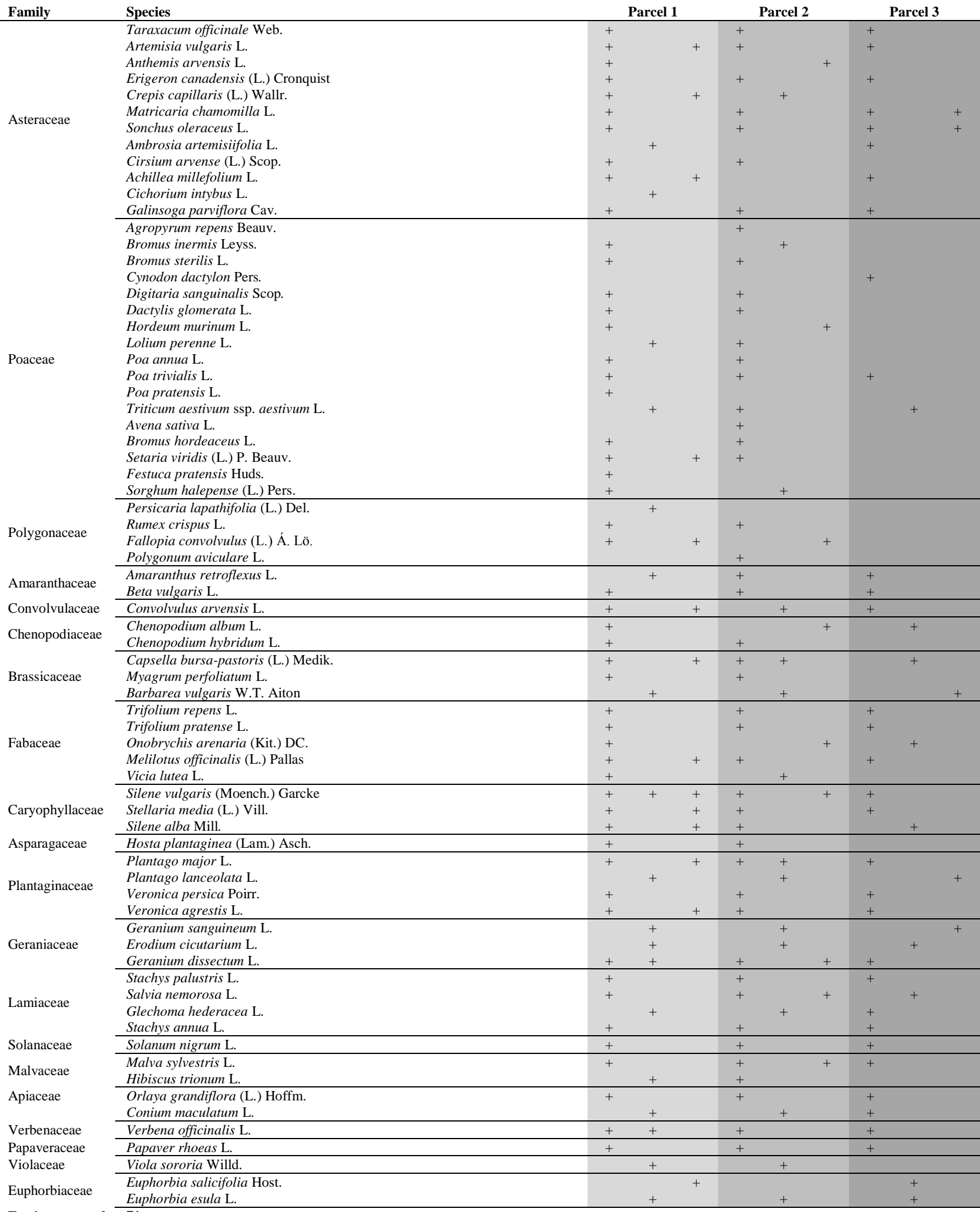

Total no. of $\mathbf{7 1}$

species

* Each column within a parcel indicates the pre-harvest period. 


\section{ACKNOWLEDGEMENTS}

We thank the two anonymous reviewers whose comments and suggestions helped improve and clarify our initial manuscript.

\section{REFERENCES}

Becker, B., A. Feller., M. Alami., E. Dubois, \& A. Plorard. (1998). A nonameric core sequence is required upstream of the LYS genes of Saccharomyces cerevisiae for Lys14p-mediated activation and apparent repression by Lysine. Molecular Microbiology, 29(1), 151-163. doi:10.1046/j.1365-2958.1998.00916.x

Boschetti, N., Quintero, C.E., Mayer, J.E., Bareta, M.R. \& Benavidez, R.A. (1998). Tissue plant analysis in evaluation of nutritional status of alfalfa meadows. Revista Científica Agropecuaria, 2, 13-20.

Doll, J.D. (1986). Do weeds affect forage quality? Pages $161-170$ in Proceedings of the $16^{\text {th }}$ National Alfalfa Improvement Symposium, Fort Wayne, IN.

Euro+Med (2006-). Euro+Med PlantBase - the information resource for Euro-Mediterranean plant diversity. Published on the Internet http://ww2.bgbm.org/EuroPlusMed/ [accessed: 02.10.2017].

Fan, J.W., Du, Y.L., Wang, B.R., Turner, N.C., Wang, T., Abbott, L.K., Stefanova, K., Siddique, K.H.M., Li, F.M. (2016). Forage yield, soil water depletion, shoot nitrogen and phosphorus uptake and concentration, of young and old stands of alfalfa in response to nitrogen and phosphorus fertilisation in a semiarid environment. Field Crops Research, 198, 247-257. doi:10.1016/j.fcr.2016.08.014

Fischer, A.J., J. H.Dawson, \& A.P. Appleby. (1988). Interference of annual weeds in seedling alfalfa (Medicago sativa). Weed Science, 36, 583-588.

Gu, Y-J., Han, Ch-L., Fan, J-W., Shi, X-P., Kong, M., Shi, X-Y., Siddique, K. H. M., Zhao, Y-Y., Li, FM. (2018). Alfalfa forage yield, soil water and $P$ availability in response to plastic film mulch and $\mathrm{P}$ fertilization in a semiarid environment. Field Crops Research, 215, 94-103 doi:10.1016/j.fcr.2017.10.010

Jefferson, P.G., Cutforth, H.W. (1997). Sward age and weather effects on alfalfa yield at a semi-arid location in southwestern Saskatchewan. Canadian Journal of Plant Science, 77, 595-599. doi:10.4141/P96-110
Karimi, H. (2007). Forage crops breeding and cultivation. University of Tehran. Iran. p. 414.

Marten, G.C., C.C. Shaffer, \& D.L. Wyse. (1987). Forage nutritive value and palatability of perennial weeds. Agronomy Journal, 79, 980-986. doi:10.2134/agronj1987.00021962007900060006x

Raoofi, M., Khanjani, M., Daneshian, J., \& Giti, S. (2014). Integrated Weed management in Perennial Alfalfa (Medicago sativa L.) and theirs effects on soil's micro fauna. International Journal of Farming and Allied Sciences, 3(4), 430-435.

Riley, E.B. \& Bradley, K.W. (2014). Influence of Application Timing and Glyphosate Tank-Mix Combinations on the Survival of GlyphosateResistant Giant Ragweed (Ambrosia trifida) in Soybean. Weed Technology. 28(1), 1-9. doi:10.1614/WT-D-13-00098.1

Shabani, G., Chaichi, M. R., Ardakani, M. R., Fridel, J. K., \& Khavazi, K. (2017). Effect of different fertilizing and farming systems in annual medic (Medicago scutellata 'Robinson') on soil organic matter and nutrients status. Acta Agriculturae Slovenica, 109(1), 5-13. doi:10.14720/aas.2017.109.1.01

Temme, D.G., R.S. Harvey, R.S. Fawcett, and A.W. Young. (1979). Effects of annual weed control on alfalfa forage quality. Agronomy Journal, 71, 5154. doi:10.2134/agronj1979.00021962007100010012x

Tutin, H.G., Heywood, V.H., Burges, N.A., Moore, D.M., Valentine, D.H., Walters, S.M., Webb, D.A. (1972). Flora Europaea, Vol. III. Cambridge University Press, Cambridge, United Kingdom.

Tutin, H.G., Heywood, V.H., Burges, N.A., Moore, D.M., Valentine, D.H., Walters, S.M., Webb, D.A. (1976). Flora Europaea, Vol. IV. Cambridge University Press, Cambridge, United Kingdom.

Tutin, H.G., Heywood, V.H., Burges, N.A., Moore, D.M., Valentine, D.H., Walters, S.M., Webb, D.A. (1980). Flora Europaea, Vol. V. Cambridge University Press, Cambridge, United Kingdom.

Tutin, H.G., Heywood, V.H., Burges, N.A., Valentine, D.H., Walters, S.M., Webb, D.A. (1964). Flora 
The effect of weed frequency in the overall alfalfa (Medicago sativa L.) productivity, case study from Kosovo

Europaea, Vol. I. Cambridge University Press, Cambridge, United Kingdom.

Tutin, H.G., Heywood, V.H., Burges, N.A., Valentine, D.H., Walters, S.M., Webb, D.A. (1968). Flora Europaea, Vol. II. Cambridge University Press, Cambridge, United Kingdom.

Wang, X. L., Cui, W. J., Feng, X. Y., Zhong, Zh. M., Li, Y., Chen, W. X., Chen, W. F., Shao, X. M., Tian, Ch. F. (2018). Rhizobia inhabiting nodules and rhizosphere soils of alfalfa: A strong selection of facultative microsymbionts. Soil Biology and Biochemistry, 116, 340-350. doi:10.1016/j.soilbio.2017.10.033

Wilson, R. G. (1981). Weed control in established dryland alfalfa (Medicago sativa). Weed Science, 29, 615-618.

Wilson, R. G. (1997). Downy brome (Bromus tectorum) control in established alfalfa (Medicago sativa).
Weed Technology, 11, 277-282. doi:10.1017/S0890037X00042950

Wilson, R.G. and Burgener, P.A. (2009). Evaluation of glyphosatetolerant and conventional alfalfa weed control systems during the first year of establishment. Weed Technology, 23, 257-263. doi:10.1614/WT-08-082.1

Zhao, C.Y., Feng, Z.D., Chen, G.D., (2004). Soil water balance simulation of alfalfa (Medicago sativa L.) in the semiarid Chinese Loess Plateau. Agric. Water Management, 69, 101-114. doi:10.1016/j.agwat.2004.04.006

Zimdahl, R.L. (2004). The effect of competition duration. Pages 109-130 in R. L. Zimdahl, ed. Weed-crop competition: A review. 2nd ed. Ames, IA: Blackwell. doi:10.1002/9780470290224.ch6 